Gi respons på artikler gjennom artiklenes kommentarfelt på tidsskriftet.no. Innleggene publiseres fortløpende på Tidsskriftets nettside og et utvalg av innleggene publiseres også i papirutgaven i spalten «Brev til redaktøren».

Redaksjonen forbeholder seg retten til å foreta redaksjonelle endringer.

Forfattere av vitenskapelige artikler har tilsvarsrett, jf. Vancouver-gruppens regler.

\section{Re: Vaginal progesteronbehandling i graviditet forebygger ikke for tidlig fødsel}

Morken \& Jacobsson skriver i Tidsskriftet nr. 9/2016 (1) at Norsk veileder i fødselshjelp 2014 (2) må oppdateres og at kvinner med tidligere preterm fødsel ikke bør få progesteron. Ifølge en ny studie (3) ga ikke vaginalt progesteron redusert risiko for preterm fødsel. Progesteronbehandling i svangerskapet samvarierte hverken med skade eller fordelaktig utkomme hos barn ved to års alder. Imidlertid hadde behandlingsgruppen færre neonatale dødsfall (1/600 mot $6 / 537$, ujustert odds ratio 0.17 ) og en reduksjon i hjerneskade påvist ved neonatal ultralyd ( $3 \%$ mot $6 \%$, ujustert odds ratio 0.50$)$. Hvorfor disse neonatale forskjellene ikke gjenspeiles i fordelaktig utkomme ved to års alder er usikkert, og kan skyldes målemetodene eller postnatale faktorer som studien ikke kan gjøre rede for.

Vi skrev kapittelet om preterm fødsel i Norsk veileder i fødselshjelp 2014 (2) før den aktuelle studien var publisert (3). Det forelå derimot to metaanalyser som viste at progesteronbehandling reduserte andelen kvinner med preterm fødsel, perinatal mortalitet og neonatal morbiditet $(4,5)$. Den første inkluderte fem randomiserte kontrollerte studier ( 775 kvinner, cervix $\leq 25 \mathrm{~mm}$ ). Progesteronbehandling reduserte risiko for fødsel $<33$ uker (relativ risiko 0.58), neonatal morbiditet og mortalitet (relativ risiko 0.57 ), respiratorisk distress syndrom, fødselsvekt $<1500 \mathrm{~g}$ og behov for mekanisk ventilasjon sammenlignet med placebogruppen (4). Den andre inkluderte 36 randomiserte kontrollerte studier (8 500 kvinner). Hos kvinner med tidligere preterm fødsel reduserte progesteronbehandling risiko for perinatal død (seks studier; 1453 kvinner; risk ratio 0.50 ), fødsel < 34 uker (fem studier; 602 kvinner; gjennomsnittlig risk ratio 0.31) og neonatal død (seks studier; 1453 kvinner; risk ratio 0.45 ). For kvinner med kort cervix reduserte progesteronbehandling risiko for fødsel $<34$ uker (to studier; 438 kvinner; risk ratio 0.64 ) og < 28 uker (to studier; 1115 kvinner; risk ratio 0.59) (5). På denne bakgrunn anbefalte vi vaginalt progesteron for å forebygge preterm fødsel hos kvinner med tidligere preterm fødsel eller tilfeldig påvist kort cervix i svangerskapet. Vi skrev at det forelå begrenset informasjon om langtidseffekter for barnet og at flere studier behøvdes (2).

Vi mener at anbefalingene ikke kan endres fordi det publiseres én studie som går i mot tidligere metaanalyser. Den nye studien bidrar til kunnskapsgrunnlaget, men har sine svakheter. Bare $69 \%$ av deltagerne brukte preparatet slik det var foreskrevet. Analyser av «intention - to - treat» vil påvirkes av cross-over mellom randomiserte grupper og bidra til å «vanne ut» en reell effekt. Videre ble inklusjonskriteriene endret etter studiestart for å inkludere flere risikokvinner i studien. Progesteronbehandlingen startet ved 22 til 24 svangerskapsuker (3), altså senere enn norske anbefalinger (2). Studien kan derfor ha underestimert effekten av progesteron på grunn av sen behandlingsstart. Det trengs nye systematiske kunnskapsgjennomganger før vi eventuelt kan endre anbefalingene. Inntil nye metaanalyser foreligger vil vi fortsatt anbefale våre norske kolleger å følge Norsk veileder i fødselshjelp fra 2014.

Trond Michelsen

trmi1@ous-hf.no

Liv Ellingsen

Katrine Sjøborg

Kjell-Åsmund Salvesen
Trond Michelsen (f. 1976) er overlege med PhD ved Fødeavdelingen Rikshospitalet ved Oslo universitetssykehus.

Ingen oppgitte interessekonflikter.

Liv Ellingsen (f. 1954) er overlege ved Fødeavdelingen Rikshospitalet ved Oslo universitetssykehus.

Ingen oppgitte interessekonflikter.

Katrine Sjøborg (f. 1968) er seksjonsoverlege med PhD ved Fødeavdelingen ved Sykehuset Østfold.

Ingen oppgitte interessekonflikter.

Kjell Åsmund Salvesen (f. 1958) er professor ved Norges teknisk-naturvitenskapelige universitet og fagdirektør ved Helse Midt-Norge. Ingen oppgitte interessekonflikter.

\section{Litteratur}

1. Morken NH, Jacobsson B. Vaginal progesteronbehandling i graviditet forebygger ikke for tidlig fødsel. Tidsskr Nor Legeforen 2016; 136: 794.

2. Veileder i fødselshjelp 2014. http://legeforeningen.no/Fagmed/ Norsk-gynekologisk-forening/Veiledere/Veileder-i-fodselshjelp-2014/ Truende-for-tidlig-fodsel/ (21.5.2016)

3. Norman JE, Marlow N, Messow CM et al. Vaginal progesterone prophylaxis for preterm birth (the OPPTIMUM study): a multicentre, randomised, double-blind trial. Lancet 2016: S0140-6736(16)00350-0.

4. Romero R, Nicolaides K, Conde-Agudelo A et al. Vaginal progesterone in women with an asymptomatic sonographic short cervix in the midtrimester decreases preterm delivery and neonatal morbidity: a systematic review and metaanalysis of individual patient data. Am J Obstet Gynecol 2012; 206: 124.e1-19.

5. Dodd JM, Jones L, Flenady V et al. Prenatal administration of progesterone for preventing preterm birth in women considered to be at risk of preterm birth. Cochrane Database Syst Rev 2013; nr. 7: CD004947.

\section{Re: Spesialistutdanningen for leger - tydelig ansvar, bedre kvalitet}

Det er positivt at styringsgruppen for ny spesialistutdanning for leger redegjør for sitt utkast for ny spesialiststruktur (1). Den nye ordningen skal tre i kraft allerede fra september 2017. Spørsmålet som melder seg er hvorfor en har bestemt oppstartsdato når forslaget enda ikke er ferdigstilt. Burde en ikke ha en modell med færre usikkerhetsmomenter før en fastsetter startdato? Siden vi allerede har et system for spesialistutdanning, burde en være sikker på at et nytt system har utsikter til å være en forbedring av det eksisterende.

\section{Håkon Kvåle \\ Hakonkvalebakke@gmail.com}

Håkon Kvåle (f. 1984) er lege i spesialisering i anestesi/førsteamanuensis ved Helgelandssykehuset Mo i Rana.

Ingen oppgitte interessekonflikter.

\section{Litteratur}

1. Arntzen E, Sandset PM. Spesialistutdanningen for leger - tydelig ansvar, bedre kvalitet. Tidsskr Nor Legeforen 2016; 136: 898-9. 